\title{
INVESTIGATION OF ATTITUDES TOWARDS Computer Programming In Terms OF VARIOUS VARIABLES
}

\author{
Abdulkadir Karaci \\ Department of Computer Engineering, Kastamonu University, Turkey
}

\begin{abstract}
This study aims to determine the attitudes of individuals towards computer programming in terms of various variables. The study group consists of the students of Kastamonu University Department of Computer Education and Instructional Technologies Teaching (CEIT), Department of Computer Engineering, and Department of Computer Programming. Data were collected via Attitude towards Computer Programming Scale (AtCPS).The results of this study show that students have neutral attitudes towards computer programming in general. Male computer programming students have significantly higher attitudes towards programming in comparison to female computer programming students. In addition, attitude towards computer programming statistically varies by grade. The higher is grade, the lower is attitude. The more time CEIT and computer programming students spend on computer for programming purposes daily, the more positive attitudes they have towards programming. Attitude significantly varies by graduated high school only among CEIT students.
\end{abstract}

\section{KEYWORDS}

Programming; attitude towards programming; attitude scale

\section{INTRODUCTION}

Computer programming becomes more important as a field of occupation every passing day at the present time, which witnesses a rapid development in information sector. However, research shows a substantial fall in the number of students selecting computer sciences as a field of study in the last decade. Computer programming requires high-level thinking skills such as problemsolving, logical thinking, and mathematical thinking [1,2]. Programming is quite a complex process each subtask of which involves a different knowledge domain and different cognitive process. Today, this skill is considered one of the most important technological literacy types. Literature contains studies on attitude towards computer programming though they are few in number. Başer [2] conducted a study on CEITand computer engineering students and concluded that it is difficult to argue that students have positive attitudes towards programming; male students have significantly more positive attitudes towards programming in comparison to female students; and though pre-service engineers have quite positive attitudes towards programming, CEITstudents have neutral attitudes. Özyurt and Özyurt [1] carried out a study on computer programming students and found that they have positive attitudes towards programming, and students' attitudes towards programming statistically vary by gender, grade, and learning type. Korkmaz and Altun [3] determined that the attitudes of students towards computer programming are not positive enough; computer engineering students have more positive attitudes in

DOI : 10.5121/ijpla.2016.6201 
comparison to the students of other departments; and university attended and gender are influential on the attitudes of students.

The present study aims to investigate the attitudes of computer engineering, CEIT, and computer programming students towards programming in terms of gender, grade, graduated high school type, and daily time spent on computer for programming purposes.

\section{RESEARCH AIM AND QUESTIONS}

The aim of this study is to investigate the attitudes of undergraduate and associate students who have received the Computer Programming Language course at least at algorithm level towards programming in terms of various variables.

In this regard, the main research question is as follows: What are the attitudes of students towards programming like?

Sub-questions of the study are given below. These sub-questions were independently handled for each department.

1. Does attitude towards programming vary by gender?

2. Does attitude towards programming vary by grade?

3. Does attitude towards programming vary by graduated high school type?

4. Does attitude towards programming vary by the daily time spent on computer for programming purposes?

\section{METHOD}

\subsection{Study Group}

The study group consists of the students of Kastamonu University Department of Computer Education and Instructional Technologies Teaching (CEIT), Computer Engineering, and Computer Programming. The study group is made up of 1 st, 2 nd, and 3rd grade undergraduate and associate students who have received the programming course at least at algorithm level. Table 1 presents the distribution of the participants by department, grade, and gender.

Table 1. The Distribution of the Sample by Total Number of Students, Grade, and Gender

\begin{tabular}{|l|c|c|c|c|c|c|}
\hline \multirow{2}{*}{ Department } & \multicolumn{2}{|c|}{ Gender } & \multicolumn{3}{c|}{ Grade } & Total Number of \\
\cline { 2 - 6 } & Female & Male & $\mathbf{1}$ & $\mathbf{2}$ & $\mathbf{3}$ & 32 \\
\hline Computer Engineering & 18 & 14 & 18 & 14 & - & 45 \\
\hline CEIT & 18 & 27 & - & 27 & 18 & 73 \\
\hline Computer programming & 20 & 53 & 22 & 51 & - & 150 \\
\hline $\begin{array}{l}\text { Total Number of } \\
\text { Students }\end{array}$ & 56 & 94 & 40 & 92 & 18 & 18 \\
\hline
\end{tabular}




\subsection{Data Collection Tool}

The data were collected through a two-part measurement tool. The first part of this measurement tool is the personal information part involving questions about gender, department, grade, graduated high school type, and daily time spent on computer for programming purposes. The second part, on the other hand, is the "Attitudes towards Computer Programming Scale (AtCPS)". AtCPS was developed by Başer [2]. This is a 5-point Likert-type scale composed of 38 items and the following four factors: "self-confidence and motivation in programming", "benefit of programming", "attitude towards success in programming", and "social perception of success in programming". The validity and reliability study of the scale was carried out by Başer [2] who found its Cronbach's $\alpha$ reliability coefficient to be 0.953 .

\subsection{Data Collection}

The administration of the scale lasted 15 to 20 minutes. The participants expressed their levels of agreement with the items through a 5-point Likert-type rating scale varying between "I Strongly Disagree" (1) and "I Strongly Agree" (5). The data were collected over the Internet through the online scale prepared on computer.

\subsection{Data Analysis}

According to Yenilmez [4], to increase statistical clarity, the score intervals of five-point Likerttype scales can be categorized as follows: "I definitely disagree (1.0-1.80)"; "I disagree (1.812.60)"; "I am neutral (2.61-3.40)"; "I agree (3.41-4.20)"; and "I definitely agree (4.21-5.0)". The intervals indicated by Yenilmez [4] were used in AtCPS employed in the present study [1,4].

Coefficient of skewness, Shapira-Wilk value, and Kolmogorov-Smirnov value were independently calculated for each department in order to determine the statistical tests to be used in data analysis. The coefficient of skewness was calculated according to the following formula: 3 (mean-median)/(Standard deviation). The coefficient of skewness was found to be 0.34, 0.39, and -0.18 for CEIT, computer engineering, and computer programming respectively. To Büyüköztürk [5], a coefficient of skewness between -1 and +1 indicates that distribution does not have too much standard deviation. In addition, since the number of computer programming individuals in the study group was over 50, Shapiro-Wilk normality test was carried out. Since the number of CEIT and computer engineering students in the study group was below 50, Kolmogorov-Smirnov normality test was carried out. As these tests yielded the result $\mathrm{p}>.05$, the data were seen to have normal distribution. Independent samples t-test and one-way ANOVA, which are parametric statistics, were used in data analysis. Bonferonni coefficient was used for the post-hoc analyses of the ANOVA test. Because ANOVA test sub-groups were different in terms of the number of people, Bonferonni coefficient was used for minimizing Type I error. Bonferonni coefficient was determined by use of the formula $.05 /$ the number of operations $(.05$ being the accepted significance level). Accordingly, .05/6=.008 was accepted as the new significance level. The comparison of the sub-groups was interpreted based on the new significance level.During data analysis, the results were evaluated based on 4 factors and the entire scale. 


\section{FINDINGS AND DISCUSSION}

\subsection{The attitudes of students towards programming}

Table 2 presents the lowest scores and the highest scores achieved by the computer engineering, CEIT, and computer programming students in AtCPS as well as their general score averages. Score averages in the Table 2 show that the students have neutral attitudes towards programming in Factor 1, Factor 2, and the entire scale. They have positive attitudes towards Factor 3. In other words, the students have positive "attitudes towards success in programming". The students consider success in programming important. However, they have negative attitudes towards Factor 4. That is to say, they have negative attitudes towards "social perception of success in programming". The students think that success in the programming course does not influence their social environment and position.

Table 2. The Score averages achieved by the students in AtCPS

\begin{tabular}{|l|l|l|c|c|c|}
\hline Department & Factor & $\mathbf{N}$ & Minimum & Maximum & Mean \\
\hline \multirow{5}{*}{$\begin{array}{l}\text { Computer } \\
\text { Engineering }\end{array}$} & $\mathrm{F} 1$ & 32 & 2.65 & 3.41 & 3.0460 \\
\cline { 2 - 6 } & $\mathrm{F} 2$ & 32 & 2.60 & 3.30 & 2.9875 \\
\cline { 2 - 6 } & $\mathrm{F} 3$ & 32 & 2.88 & 4.00 & 3.7148 \\
\cline { 2 - 6 } & $\mathrm{F} 4$ & 32 & 1.00 & 3.33 & 1.5938 \\
\cline { 2 - 6 } & Scale & 32 & 2.57 & 3.23 & 2.8355 \\
\hline \multirow{5}{*}{ CEIT } & $\mathrm{F} 1$ & 45 & 2.53 & 3.59 & 2.9765 \\
\cline { 2 - 6 } & $\mathrm{F} 2$ & 45 & 2.50 & 3.40 & 2.9689 \\
\cline { 2 - 6 } & $\mathrm{F} 3$ & 45 & 2.50 & 4.50 & 3.6639 \\
\cline { 2 - 6 } & $\mathrm{F} 4$ & 45 & 1.00 & 3.67 & 1.7333 \\
\cline { 2 - 6 } & Scale & 45 & 2.52 & 3.38 & 2.8356 \\
\hline \multirow{5}{*}{$\begin{array}{l}\text { Pomputer } \\
\text { Programming }\end{array}$} & $\mathrm{F} 1$ & 73 & 2.47 & 3.53 & 3.0492 \\
\cline { 2 - 6 } & $\mathrm{F} 2$ & 73 & 2.60 & 3.60 & 3.0740 \\
\cline { 2 - 6 } & $\mathrm{F} 3$ & 73 & 3.00 & 4.63 & 3.7466 \\
\cline { 2 - 6 } & $\mathrm{F} 4$ & 73 & 1.00 & 3.00 & 1.6438 \\
\cline { 2 - 6 } & Scale & 73 & 2.55 & 3.24 & 2.8784 \\
\hline
\end{tabular}

\subsection{Variation of Attitude Towards Programming by Gender}

Whether or not attitude towards programming varies by gender was independently investigated in all departments via independent samples t-test. The average scores of the male students and the female students were independently calculated for the departments. Independent samples t-test analyses were also independently made for the departments. The obtained results are given in Table 3. The data are showed in the table for the entire scale and for the factors involving significant variation. 
Table 3. T-test Results Concerning the Averages of the Female Students and the Male Students

\begin{tabular}{|c|c|c|c|c|c|c|c|c|c|}
\hline Department & Factor & Gender & $\mathbf{N}$ & Mean & Sd & $\begin{array}{l}\text { Std. Error } \\
\text { Difference }\end{array}$ & $\mathbf{t}$ & df & $\mathbf{p}$ \\
\hline \multirow{2}{*}{$\begin{array}{l}\text { Computer } \\
\text { Engineering }\end{array}$} & \multirow{2}{*}{ Scale } & Female & 18 & 2.82 & .11 & 0.05 & \multirow{2}{*}{.528} & \multirow{2}{*}{30} & \multirow{2}{*}{.6} \\
\hline & & Male & 14 & 2.85 & .19 & 0.02 & & & \\
\hline \multirow{2}{*}{ CEIT } & \multirow{2}{*}{ Scale } & Female & 18 & 2.81 & .18 & 0.04 & \multirow{2}{*}{.585} & \multirow{2}{*}{43} & \multirow{2}{*}{.56} \\
\hline & & Male & 27 & 2.84 & .19 & 0.03 & & & \\
\hline \multirow{4}{*}{$\begin{array}{l}\text { Computer } \\
\text { Programming }\end{array}$} & \multirow{2}{*}{$\mathrm{F} 1$} & Female & 20 & 2.95 & .22 & 0.05 & \multirow{2}{*}{2.262} & \multirow{2}{*}{71} & \multirow{2}{*}{.027} \\
\hline & & Male & 53 & 3.08 & .23 & 0.03 & & & \\
\hline & \multirow{2}{*}{ Scale } & Female & 20 & 2.81 & .19 & 0.04 & \multirow{2}{*}{2.264} & \multirow{2}{*}{71} & \multirow{2}{*}{.027} \\
\hline & & Male & 53 & 2.90 & .13 & 0.01 & & & \\
\hline
\end{tabular}

The Table 3 indicates that the male computer programming students have significantly higher attitudes than the female computer programming students. This result is similar to the results of Başer[2], Özyurt and Özyurt [1], Aşkar and Davenport [6], and Korkmaz and Altun [3]. However, no significant difference was found between the female computer engineering and CEIT students and the male computer engineering and CEIT students. This result is similar to the result of Altun and Mazman [7].

\subsection{Variation of Attitude Towards Programming by Grade}

Whether or not attitude towards programming varies by grade was independently investigated in all departments via independent samples t-test. The average scores of the students from different grades were independently calculated for the departments. Independent samples t-test analyses were also independently made for the departments. The obtained results are given in Table 4 . The data are showed in the table for the entire scale and for the factors involving significant variation.

Table 4. T-test results concerning the averages of the students by grade

\begin{tabular}{|c|c|c|c|c|c|c|c|c|c|}
\hline Department & Factor & Grade & $\mathbf{N}$ & Mean & Sd & $\begin{array}{l}\text { Std. Error } \\
\text { Difference }\end{array}$ & $\mathbf{t}$ & df. & $\mathbf{p}$ \\
\hline \multirow{4}{*}{$\begin{array}{l}\text { Computer } \\
\text { Engineering }\end{array}$} & \multirow{2}{*}{$\mathrm{F} 1$} & 1 & 18 & 3.10 & .20 & .04 & \multirow{2}{*}{2.144} & \multirow{2}{*}{30} & \multirow{2}{*}{.040} \\
\hline & & 2 & 14 & 2.97 & .13 & .03 & & & \\
\hline & \multirow{2}{*}{ Scale } & 1 & 18 & 2.84 & .09 & .02 & \multirow[b]{2}{*}{.539} & \multirow[b]{2}{*}{30} & \multirow[b]{2}{*}{.594} \\
\hline & & 2 & 14 & 2.81 & .20 & .05 & & & \\
\hline \multirow{4}{*}{ CEIT } & \multirow{2}{*}{$\mathrm{F} 2$} & 2 & 27 & 3.01 & .12 & .02 & \multirow{2}{*}{2.098} & \multirow[b]{2}{*}{43} & \multirow[b]{2}{*}{.042} \\
\hline & & 3 & 18 & 2.90 & .21 & .05 & & & \\
\hline & \multirow[b]{2}{*}{ Scale } & 2 & 27 & 2.88 & .19 & .03 & \multirow[b]{2}{*}{2.262} & \multirow[b]{2}{*}{43} & \multirow[b]{2}{*}{.029} \\
\hline & & 3 & 18 & 2.76 & .14 & .03 & & & \\
\hline \multirow{4}{*}{$\begin{array}{l}\text { Computer } \\
\text { Programming }\end{array}$} & \multirow{2}{*}{ F3 } & 1 & 22 & 3.91 & .31 & .06 & \multirow{2}{*}{2.815} & \multirow{2}{*}{71} & \multirow{2}{*}{.006} \\
\hline & & 2 & 51 & 3.67 & .34 & .04 & & & \\
\hline & \multirow{2}{*}{ Scale } & 1 & 22 & 2.90 & .16 & .03 & \multirow{2}{*}{.835} & \multirow{2}{*}{71} & \multirow{2}{*}{.407} \\
\hline & & 2 & 51 & 2.86 & .15 & .02 & & & \\
\hline
\end{tabular}


The Table 4 shows that attitude towards programming statistically varies by grade. The higher is grade, the lower is attitude. This result is different from that of Özyurt and Özyurt [1].

When a detailed evaluation is made, it is seen that the significant variation by grade is true for only Factor 1 for the department of computer engineering. That means that "self-confidence and motivation in programming" decreases as grade increases. There is a significant difference between CEIT students in Factor 2 and the entire scale. Attitude towards the "benefit of programming" decreases as grade increases. There is a significant difference between computer programming students in Factor 3. As grade increases, "attitude towards success in programming" decreases.

Reasons for decrease in attitude as a result of increase in grade should be investigated. There may be several reasons (e.g. the number of programming courses increases; programming lessons become more complicated; students fail in lessons; study load increases).

\subsection{Variation of Attitude Towards Programming by the Time Spent on Computer for Programming Purposes}

Whether or not attitude towards programming varies by the daily time spent on computer for programming purposes was independently investigated in all departments via one-way ANOVA. The ANOVA results are given in Table 5.

Table 5. The ANOVA results concerning the attitude towards programming scale scores by the daily time spent on computer for programming purposes

\begin{tabular}{|c|c|c|c|c|c|c|c|c|}
\hline Department & Factor & $\begin{array}{l}\text { Source of } \\
\text { Variance } \\
\end{array}$ & $\begin{array}{c}\text { Sum of } \\
\text { Squares }\end{array}$ & Sd & $\begin{array}{c}\text { Mean } \\
\text { Square }\end{array}$ & $\mathbf{F}$ & p & $\begin{array}{l}\text { Significant } \\
\text { Difference }\end{array}$ \\
\hline \multirow{3}{*}{$\begin{array}{l}\text { Computer } \\
\text { Engineering }\end{array}$} & \multirow{3}{*}{ Scale } & Intergroup & .035 & 3 & .012 & \multirow{3}{*}{.470} & \multirow{3}{*}{.706} & \multirow{3}{*}{ No } \\
\hline & & In-group & .687 & 28 & .025 & & & \\
\hline & & Total & .721 & 31 & & & & \\
\hline \multirow{3}{*}{ CEIT } & \multirow{3}{*}{ Scale } & Intergroup & .274 & 3 & .091 & \multirow{3}{*}{3.02} & \multirow{3}{*}{.040} & \multirow{3}{*}{$\begin{array}{l}\text { Less than } 1 \\
\text { hour and } 2 \\
\text { to } 4 \text { hours }\end{array}$} \\
\hline & & In-group & 1.237 & 41 & .030 & & & \\
\hline & & Total & 1.510 & 44 & & & & \\
\hline \multirow{3}{*}{$\begin{array}{l}\text { Computer } \\
\text { Programming }\end{array}$} & \multirow{3}{*}{ Scale } & Intergroup & .378 & 3 & .126 & \multirow{3}{*}{5.80} & \multirow{3}{*}{.001} & \multirow{3}{*}{$\begin{array}{l}2 \text { to } 4 \text { hours } \\
\text { and more } \\
\text { than } 4 \\
\text { hours }\end{array}$} \\
\hline & & In-group & 1.496 & 69 & .022 & & & \\
\hline & & Total & 1.873 & 72 & & & & \\
\hline
\end{tabular}

No significant difference was found between computer engineering students in terms of attitude towards programming by the daily time spent on computer for programming purposes in any factor and in the entire scale $(F[3.28]=.47, \mathrm{p}>.05)$.

While no significant difference was found between CEIT students in factors, a significant difference was detected between them in the entire scale $(F[3.41]=3.024, \mathrm{p}<.05)$. In other words, there is a significant difference between the attitudes of CEIT students towards computer programming by the daily time spent on computer for programming purposes. Since the number of data was small, the Bonferroni test was carried out in order to find the groups between which 
there is a difference by the daily time spent on computer for programming purposes. The test results show that the students spending 2 to 4 hours on computer for programming purposes daily $(\overline{\mathrm{X}}=3.01, \mathrm{D}=0.29)$ have more positive attitudestowards computer programming in comparison to students spending less than 1 hour on computer for programming purposes daily $(\bar{X}=2.76$, $\mathrm{D}=0.15)$.

A significant difference was found between the computer programming students in the entire scale while no significant was found between them in factors $(F[3.69]=5.806, p<.05)$. In other words, the attitudes of computer programming students towards computer programming significantly vary by the daily time spent on computer for programming purposes. The Bonferroni test was carried out in order to find the groups between which there is a difference by the daily time spent on computer for programming purposes. The test results demonstrate that the students spending more than 4 hours on computer for programming purposes daily $(\bar{X}=2.97$, $\mathrm{D}=0.19$ ) have more positive attitudes towards programming in comparison to those who spend 2 to 4 hours on computer for programming purposes daily $(\bar{X}=2.66, D=0.056)$.

These analysis results indicate that computer programming students and CEIT students have more positive attitudes towards programming as the daily time spent on computer for programming purposes increases.

\subsection{Variation of Attitude Towards Programming by Graduated High School Type}

Whether or not attitude towards programming varies by graduated high school type was independently investigated in all departments via one-way ANOVA. The ANOVA results are given in Table 6.

Table 6. The ANOVA results concerning the attitude towards programming scale scores by graduated high school type

\begin{tabular}{|c|c|c|c|c|c|c|c|c|}
\hline Department & Factor & $\begin{array}{l}\text { Source of } \\
\text { Variance }\end{array}$ & $\begin{array}{c}\text { Sum of } \\
\text { Squares }\end{array}$ & Sd & $\begin{array}{c}\text { Mean } \\
\text { Square }\end{array}$ & $\mathbf{F}$ & $\mathbf{p}$ & $\begin{array}{l}\text { Significant } \\
\text { Difference }\end{array}$ \\
\hline \multirow{3}{*}{$\begin{array}{l}\text { Computer } \\
\text { Engineering }\end{array}$} & \multirow{3}{*}{ Scale } & Intergroup & .069 & 3 & .023 & \multirow{3}{*}{.992} & \multirow{3}{*}{.411} & \multirow{3}{*}{ No } \\
\hline & & In-group & .652 & 28 & .023 & & & \\
\hline & & Total & .721 & 31 & & & & \\
\hline \multirow{3}{*}{ CEIT } & \multirow{3}{*}{ Scale } & Intergroup & .289 & 3 & .096 & \multirow{3}{*}{3.239} & \multirow{3}{*}{.032} & \multirow{3}{*}{$\begin{array}{l}\text { General/Regular } \\
\text { high schools } \\
\text { with Vocational } \\
\text { high schools }\end{array}$} \\
\hline & & In-group & 1.221 & 41 & .030 & & & \\
\hline & & Total & 1.510 & 44 & & & & \\
\hline \multirow{3}{*}{$\begin{array}{l}\text { Computer } \\
\text { Programming }\end{array}$} & \multirow{3}{*}{ Scale } & Intergroup & .021 & 3 & .007 & \multirow{3}{*}{.263} & \multirow{3}{*}{.852} & \multirow{3}{*}{ No } \\
\hline & & In-group & 1.852 & 69 & .027 & & & \\
\hline & & Total & 1.873 & 72 & & & & \\
\hline
\end{tabular}

No significant difference was found between the computer engineering students in terms of attitude towards programming by graduated high school type in any factor and in the entire scale $(\mathrm{F}[3.28]=.992, \mathrm{p}>.05)$. A great majority of the computer engineering students included in the study were graduated from Anatolian high schools (18) and general/regular high schools (12). In other words, there is no difference between the attitudes of the computer engineering students who were graduated from Anatolian high schools and those of the computer engineering students who were graduated from general/regular high schools. 
While no significant difference was found between CEIT students in the factors, a significant difference was found between them in the entire scale $(\mathrm{F}[3.41]=3.239, \mathrm{p}<.05)$ by graduated high school type. In other words, the attitudes of CEIT students towards computer programming significantly vary by graduated high school type. Since the number of data was small, the Bonferroni test was carried out in order to find the groups between which there is a difference by graduated high school type. The test results show that the students graduatingfrom general/regular high schools $(\overline{\mathrm{X}}=3.08, \mathrm{D}=0.31)$ have more positive attitudes towards programming than the students graduating from vocational high schools $(\overline{\mathrm{X}}=2.77, \mathrm{D}=0.15)$. Indeed, this is not an expected result. However, vocational high school graduates may be prejudiced because they might have had difficulty in the programming course they received in their high school years.

No significant difference was found between the computer programming students in the factors and in the entire scale $(\mathrm{F}[3.69]=.263, \mathrm{p}>.05)$ by graduated high school type. A great majority of the computer programming students included in the study graduated from vocational high schools (49), technical high schools (12), and general/regular high schools (10). In other words, there is no difference between the computer programming students graduated from these high schools in terms of attitude towards computer programming.

\section{CONCLUSION}

This study investigated the attitudes of computer engineering, CEIT, and computer programming students towards programming in terms of various variables. It was found that the students generally have neutral attitudes towards computer programming. Detailed examination for each factor demonstrates that the students have neutral attitudes towards Factor 1 and Factor 2, positive attitudes towards Factor 3, and negative attitudes towards Factor 4.

Among computer programming students, the male students have higher attitudes towards programming in comparison to the female students. There is no significant difference between the computer engineering students and between the CEIT students in terms of attitude towards programming by gender. In addition, attitude towards programming statistically varies by grade. The higher is grade, the lower is attitude. Reasons for that should be investigated based on various variables. Among CEIT students and computer programming students, positive attitudes increase as the daily time spent on computer for programming purposes increases. Attitude towards computer programming significantly varies by graduated high school type only among CEIT students.

\section{REFERENCES}

[1] Özyurt Ö., \& Özyurt, H. (2015). A study for determining computer programming students' attitudes towards programming and their programming self-efficacy, Journal of Theory and Practice in Education, 11(1), 51-67.

[2] Başer, M. (2013). Developing attitude scale toward computer programming. International Journal of Social Science, 6(6), 199-215.

[3] Korkmaz, Ö., \& Altun, H. (2013). Engineering and ceit student's attitude towards learning computer programming. The Journal of Academic Social Science Studies International Journal of Social Science, 6(2), 1169-1185.

[4] Yenilmez, K. (2008). Open primary education school students' opinions about mathematics television programmes. Turkish Online Journal of Distance Education, 9(4), 176-189.

[5] Büyüköztürk, Ş. (2009). Sosyal bilimler için veri analizi el kitabı: İstatistik, araştırma deseni, SPSS uygulamaları ve yorum (9.baskı). Ankara: Pegem Yayınları. 
International Journal of Programming Languages and Applications ( IJPLA ) Vol.6, No.1/2, April 2016

[6] Aşkar, P., \& Davenport, D. (2009). An investigation of factors related to self-efficacy for java programming among engineering students. The Turkish Online Journal of Educational Technology, $8(1), 26-32$.

[7] Altun, A., \& Mazman, S.G. (2012). Programlamaya ilişkin öz yeterlilik algısı ölçeğinin Türkçe formumun geçerlilik ve güvenirlik çalışması. Eğitimde ve Psikolojide Ölçme ve Değerlendirme Dergisi, 3(2), 297- 308.

\section{Authors}

Dr. (Mr.) Abdulkadir KARACI

Assistant professor

Department of Department of Computer Engineering

B.E. (Computer Education)

M.E. (Computer Education)

Ph.D (Electronic and Computer Education)

Areas of Interest: Intelligent Tutoring System, Artificial Neural Network, Programming Language 